\title{
Food and Nutritional Security Initiatives in Bihar (India): An Overview
}

\author{
K. M. Singh ${ }^{1 *}$, Pushpa Singh ${ }^{2}$ and Binita Rani ${ }^{3}$ \\ ${ }^{1}$ Agricultural Economic, ${ }^{2}$ Entomology, Dr Rajendra Prasad Central \\ Agricultural University, Pusa, Bihar (India) \\ ${ }^{3}$ Dairy Chemistry, SGIDT, BASU, Patna, India \\ *Corresponding author
}

\section{A B S T R A C T}

\section{Keywords}

Agriculture, Food and nutrition, Food diversity, Bihar, Institutional initiatives

\section{Article Info}

Accepted: 20 December 2020 Available Online: 10 January 2021
The agricultural pathways to improve the rural year-round access to affordable, diverse, and high-quality foods needs to include all individuals, enterprises, and institutions that influence the supply, demand, consumption, and absorption of food. The interconnected components of a food system lies in diversification of agricultural production system ensuring a level playing field for the production and marketing of nutritious non-staples, such as fresh fruits, legumes, and livestock products and creating a more robust and diversified food system. Bihar had the highest percentage of stunted children among all the states in India. Forty-two percent of children under the age of five in Bihar were stunted, a significantly higher proportion compared to the all-India average of $34.7 \%$ and IFS can bring the required diet diversity of household. The Ankuran programme aims to nudge children to eat more nutritious food by creating nutrition and hygiene awareness among students, by setting up poshan vatikas, in schools. Promotion of advanced crop production practices, bio-fortification, Poshan Vatikas, livestock to sustainably improve household availability of nutrition, conserving natural resources and redirecting agricultural policy away from "staple-grain fundamentalism" toward a much broader food systems focus, considering the need to build better connections between agriculture and nutrition.

\section{Introduction}

Bihar is the third most populace state with population of 1210.6 million and 8.6 percent to country's total population, and agriculture is the backbone of its economy with contribution of agriculture and allied sectors to GSVA 19.3 percent in 2018-19 with the largest contributor to GSVA being the crop sector (10.6 percent); while the lowest contributor was fishing and aquaculture (1.5 percent). The livestock sector is emerging as an important segment with its increasing contribution to state's GSVA from 5.4 percent in 2013-14 to 5.6 percent in 2018-19 (Bihar economic survey 19-20, Table 1). With nearly 89 percentage of population residing in rural areas and a majority depending on small land holdings for living, the need to leverage agriculture for nutrition becomes significant in Bihar as malnutrition continues to bea major challenge in Bihar. There has been a 
focus towards cereal-dominant farming systems of rice and wheat, with a decline in production of a variety of millets and pulses over time.

\section{Agricultural scenario in Bihar}

The rich Gangetic plains, fertile alluvial soil, and abundant water resources provide impetus for a diversified farming system producing both food and non-food crops. The main crops such as rice, wheat, and maize, with vegetables and fruits are cultivated with cereals occupying more than 86 percent of the gross cropped area. Within cereals, rice and wheat together contribute more than 70 percent of the total gross cropped area, pulses in gross cropped area has been declining, though there has been a revival in 2018-19. The large share of food-grains in the total gross cropped area at 94.0 percent is indicative of the subsistence farming. Pulses production presently is 4.53 lakh tonnes growing at a rate of 1.89 percent per annum during 2014-15 to 2018-19, due to growth in Rabi pulses, mainly lentil (36.5 percent), summer moong (26.3 percent) and gram (16.0 percent). The Rabi pulses have grown at a rate of 2.71 percent, with an average productivity of $897 \mathrm{~kg}$ per hectare over the five-year period whereas kharif pulses; productivity is $843.2 \mathrm{~kg}$ per hectare.

Horticulture has emerged as important agricultural enterprises offering opportunities for farmers to diversify their cropping pattern to include fruits, vegetables, flowers, spices, and plantation crops, medicinal and aromatic plants. The total production of fruits has increased from 41.05 lakh tonnes in 2016-17 to 42.29 lakh tonnes in 2018-19, with an annual growth rate of 4.9 percent and recorded highest productivity in banana, averaging around 44.94 tonnes per hectare and the lowest in case of muskmelon at 6.26 tonnes/hectare. A total of 166.03 lakh tonnes of vegetables was produced in 8.57 lakh hectares in 2018-19 and the total area has increased from about 8.28 lakh hectares to 8.57 lakh hectares, at an annual growth rate of about 1.99 percent during 2016-17 to 2018-19 with production increased from 143.62 lakh tonnes to 166.03 lakh tonnes, an annual growth rate of 7.52 percent with productivity at the rate of 18.81 percent The increasing awareness on adoption of new technology, high yielding varieties, usage of quality planting material, protected farming, micro irrigation methods and banana tissue culture plantlets have enabled growth in this sector.

Livestock and aquaculture together contributed about 7.10 percent of Gross Value Added in agriculture sector in Bihar during 2018-19, an important component of agricultural economy supplying food and nutrition, enhancing income and livelihood and diversifying of agricultural activities, contributing Rs. 1.45 lakh crores to GDP during 2016-17 to 2018-19. The milk production has steadily increased from 77.75 lakh tonnes in 2014- 15 to 98.18 lakh tonnes in 2018-19, an annual growth rate of 5.92 percent, fishery in Bihar increased from 4.79 lakh tonnes in 2014-15 to 6.02 lakh tonnes in 2018-19, an compound annual growth of 6.22 percent increasing production from 4.79 lakh tonnes in 2013-14 to 6.02 lakh tonnes in 2018-19, registering an annual growth rate of 6.22 percent and fastest growth of 14.60 percent in egg production in the same period so about 176.33 crores of eggs are produced, meat production has increased from 2.94 lakh tonnes in 2014- 15 to 3.64 lakh tonne in 201819 , an annual growth of 5.70 percent.

\section{Nutritional Profile of Bihar}

Bihar has $11 \%$ of India's under-five population or 12.7 million children. Of these 12.7 million children, $49 \%$ (6.3 million) suffer from chronic under nutrition (stunting) 
and 37\% (1.7 million) suffer from acute under nutrition (wasting). Stunting is more prevalent in the more vulnerable scheduled caste (SC) population $(58 \%$ opposed to $49 \%$ state average), wasting is marginally higher in this group. Of 43.6 million stunted Indian children, 6.3 million (14\%) live in Bihar and of the 16.9 million wasted children in India, 1.7 million (11\%) live in Bihar (Nourishing Bihar's Children UNICEF Bihar Field Office Discussion paper-DRAFT 06DEC, 2015); all this presents a very gloomy scenario. The state has undertaken several steps and over a time period of one decade there is a considerable decline in stunting wasting and underweight of children, of age under 5 years, in rural Bihar but the status of malnutrition continues to remain a challenge with nearly half of the children still malnourished and also one-fifth are wasting among children under 5 years over a decade.

Malnutrition is caused by multiple factors and any approach to tackle the problem of malnutrition would require a holistic, multidimensional approach and combination of nutrition specific as well as nutrition sensitive interventions to address this problem. Agriculture and allied activities are the main source of livelihood for nutritionally deprived sections, thus food nutrition and security is also linked to farm diversity, productivity and profitability. Following the Integrated Farming System (IFS) approach we can effectively combat malnutrition and also contribute to the economic growth story of the state.

The benefits of integrated farming systems in mitigating climate risk, diversifying diets and generating income, especially for smallholder farmers, has already been recognized and can be made nutrition-sensitive by tailoring them to address the nutritional deficiencies prevalent in a specific region.

\section{Agricultural Productivity, Food Diversity and access to household nutrition outcome}

Extraordinary rise of agricultural productivity during green revolution was largely due to increase in the productivity of cereal crops like paddy and wheat, having the positive impact calorie and protein consumption due to access to food and enhanced income (Pingali 2012,). The calorific rise in consumption of grain has not lead to improvement in nutrition status as poverty and food security persists. The increased demand for vegetables, fruit, dairy products etc have led to their increased prices as compared to cereals due policy neglect to such crops and continuance of pro-grain policies like subsidies, price support, input supply and credit programs. Traditional crops like minor millets and pulses rich in protein and micronutrient have been replaced by paddy, wheat and maize (Pingali 2015, webb 2009). The markets for non- cereal crops are underdeveloped with poor transportation facility, cold storage and food processing and value addition units due to lack of government investment and private sector interest.

To make agriculture more nutrition sensitive the need is change in policy approach with combination of nutrition sensitive interventions, infrastructure investment and producer incentives all complimenting each other and enhancing diversity, quality and safety of food system to make it accessible as well as inclusive for all. There is huge $R \& D$ gap in respect to nutritionally important crops and livestock products. On basis of socio economical and geographical specifics of any region the exact mix of crops have to be promoted without having any negative impact on cereal crops productivity but also putting adequate focus on enhancing nutrition rich non stable crops and products. The exact mix of crops to be promoted depends on the 
geographic and socio-economic context of the region and the staple crop productivity continues to be important, with adequate focus on enhancing nonstaple food crop productivity.

This fact has been laid emphasis by Dr. Swaminathan who said that to tackle nutritional maladies prevailing anywhere there is need to propound farmer led farming for nutrition through mainstreaming nutritional criteria in the selection of the components of a farming system involving crops, farm animals and wherever feasible, fish' with an aim to change food production, enhance availability and access to food for small-scale farming households.

With time we have been shrinking the food basket limiting it to fewer crops and varieties which needs to be amended by promoting nutrient rich minor millets and promoting crops like rajma, jowar, Bajra, barley besides Quality protein maize.

A major distortion of the Green Revolution has been the relative neglect of pulses production and so the per capita availability of pulses has declined in recent years resulting in decline of protein quality of diets which can be simply overcome by giving pulse production its due state in IFS and widens our food basket.

Many of the crops are disappearing due to its low economic value by linking them to markets and value addition. Vegetable based cropping system followed by small and marginal farmers are reported to have a lower deficiency from Recommended Daily

Allowance in the consumption of vitamin A , iron, and vitamin $\mathrm{C}$ for adults and for children vis-à-vis those having non-vegetable based production systems (Adhiguru and Ramasamy, 2003).

\section{Millets in food and Nutritional security}

The over-dependence on a handful of crops like rice, maize, wheat and potato, which provide over 50 per cent of the world's caloric intake (FAO, 2010), has seen hundreds of species and varieties of food plants marginalized and becoming increasingly irrelevant in national agricultural production systems. The whole system has paid less attention to neglected and underutilized minor millets which has resulted in missed nutrition and health opportunities as most of these underutilized minor millets offer a broader range of macro and micronutrients than those available in major staple crops. Once widely consumed and playing a key role in household food security and dietary diversity the minor millets have lost their importance after the green revolution replaced them with paddy and wheat; lack of research investment on these crops; their limited commercial importance in terms of area, production and consumption patterns have relegated them to the minor position (Nagarajan and Smale, 2007). However, the nutritional and income generation opportunities from millets are much higher, and over the last 10 years, there has been increasing recognition of their favourable nutritional properties and associated benefits, thanks to several national and international projects. Furthermore, they are increasingly being appreciated as healthy foods for urban and middle- income groups, losing the stigma of 'poor people's food' that was associated with them up until recently (Bala Ravi et al., 2010). Millets are hardy and resilient crop and can very easily fit in IFS for different situations. This group of smallseeded cereals is represented by six species, namely, finger millet (Eleusine coracana (L.), kodo millet (Paspalum scrobiculatum(L.)), foxtail millet (Setaria italica (L.) Pal.), little millet (Panicum sumatrense proso millet (Panicum miliaceum (L.)) and barnyard millet 
(represented by two species: Echinochloa crusgalli and E. colona (L.) (Bala Ravi, 2004; Padulosi et al., 2009). Millets are rich in vitamins, minerals (calcium and iron in particular), sulphur-containing amino acids and phytochemicals, and hence are often described as 'nutritious millets' (Bala Ravi, 2004) or 'nutri- cereals' (Choudhury, 2009). They also contain high proportions of nonstarchy polysaccharides and dietary fibre.

Aquaculture and livestock are source of diet diversification leading to an improved intake of animal-based micronutrients (Jahan et al., 2010) and integrated Farming system of agriculture-aquaculture - livestock showed a positive effect on farm productivity, micronutrient consumption, and nutritional status (Jahan and Pemsl, 2011). The milk production can influence household food consumption by enhancing the availability of milk for selfconsumption and by increasing cash income which helps in purchase of additional food commodities from the market.

The integrated farming system is one of most powerful tool for enhancing the profitability of small and marginal farmers which needs to be planned, designed, analyzed and implemented for increasing productivity, profitability and sustainability of the farm and also socially acceptable, economically viable and eco-friendly. Integration of enterprises lead to greater dividends than single enterprise based farming, especially for small and marginal farmers resulting in improvement in nutritional quality of daily diet of farmers. Jayanthi et al., (2000) described these systems as a mixed animal crop system where the animal component is often raised on agricultural waste products while the animal is used to cultivate the soil and provide manure to be used as fertilizer and fuel. The difference between mixed farming and integrated farming is that, enterprises in the integrated farming system are mutually supportive and depend on each other (Csavas, 1992), there are synergies and complements between enterprise that comprised a crop and animal component to form the basis of the IFS concept, so basically by-products of one enterprise are used as inputs for another within the context of the farming system.

Farming System approach calls for promotion of location-specific farming systems that integrate arable farming, horticulture, backyard farming and animal farming to sustainably improve household availability of nutrition while also mitigating risk and conserving natural resources.

\section{Farming Systems popular and widespread} in Bihar

Makhana Based IFS- This promotes Makana and water Chestnut Cultivation in low lying fields/shallow ponds in the districts of Katihar, Supaul, Saharsa and Purnia of Agro- Climatic Zone II of Bihar. The main highlights are: Makana and water Chestnut, Makana followed by Barsheem and Makhana followed by Summer rice or wheat having net income Rs 88790, Rs 98465 and Rs 122570 rsepectively as compared to Rs 48960/-in Makana alone cultivation. Makhana with fish and water chestnut farming is also being popularized which gives income of 88910/-

Crop Based integrated Farming system- It comprises of cultivation of Paddy, wheat, Chickpea/lentil, Dairy, Vermicompost, Fish farming and vegetables giving a net income of Rs 6.5 lakh/annum and 27 lakh in 10 ha land holding and this IFS is very popular among farmers with more and more adoption.

Fish Based integrated Farming system Inland fisheries is very popular in Bihar 
and now KVKs are transferring the technology which includes other components like vegetable cultivation on pond bank, vermicomposting, Banana and guava cultivation etc. This IFS system is giving income of Rs. 7.6 lakh from 2 ha land and 7.4 lakh in 4ha area

Vegetable based integrated Farming system: Vegetable Farming is followed by many of marginal and small farmers of Bihar and new inputs and techniques have been given to these farmers to integrate vegetable farming with other agricultural components and IFS has been popularized. This system gives additional nutrient component yielding extra money to farmer.

Mushroom based integrated Farming system: Mushroom cultivation has brought a revolution for rural women and small farmers of Bihar and Jharkhand. KVKs of this zone have transferred the technology and integrated it with Organic Farming, Fisheries, poultry and Beekeeping give an income of $6.8 \mathrm{Lakh} /$ annum.

Goat based integrated Farming system: Goat farming is consider as any time bank as it has the ability of bringing additional income to the household and goat based IFS has been promoted as livelihood alternative for women tribal community in Ranchi District which give them a net income of 1.9lakh/annum.

Climate Smart integrated Farming system: This IFS model is popularized for farmers having large holding of 2 ha land giving an income of 6.6lakh/annum.

Nutritive value of various enterprises Cereals particularly rice and wheat chiefly provide carbohydrates whereas fruits and vegetables, livestock, fishery, pulses provide vitamins, minerals, fat and protein besides carbohydrates essential for healthy living. For a living, we need $300 \mathrm{~g}$ of vegetables and 120 $\mathrm{g}$ of fruits per day besides $475 \mathrm{~g}$ cereals, $80 \mathrm{~g}$ pulses, $55 \mathrm{~g}$ protein, $450 \mathrm{mg}$ calcium, $20 \mathrm{mg}$ iron, $50 \mathrm{mg}$ Vitamin C, $1.4 \mathrm{mg}$ thiamine, 1.5 $\mathrm{mg}$ riboflavin, $19 \mathrm{mg}$ niacin, $5 \mathrm{mg}$ Vitamin $\mathrm{D}$, $1.0 \mathrm{mg}$ Vitamin B12, $100 \mathrm{mg}$ folic acid, 3000 mg B-carotene, $200 \mathrm{ml} \mathrm{milk,} 40 \mathrm{mg}$ sugar and $40 \mathrm{ml}$ of oil constituting $2800 \mathrm{~g}$ of calories (NIN, 1980 and ICMR, 2012). Predominantly the diet is insufficient in protein and other micronutrients and chief deficiencies of diet are calories, protein, Vitamin $\mathrm{A}$ and riboflavin. Thus there is a large scope to minimise malnutrition through intake of protective foods in all the IFS. Fruits and vegetables, livestock, fishery, pulses and paddy grown can provide all the essential nutrients like vitamins, minerals, fat and protein besides carbohydrates.

\section{Strengthening the linkage between Agriculture and nutrition}

Agriculture in Bihar is characterised by small and scattered farm holding, as there are about 1.61 crore farm holdings of which 91 percent is marginal so there is need of incorporating the farming systems-based approach for dietary diversity and better nutrition status of small-holder farmers. The nutri-dense crops should be promoted by developing package of practices for such crops for small farmers. Krishi Vigyan Kendras (KVKs)can build locally relevant models for nutrition farming and provide support for extension. They can also be helpful in scientific validation of nutritional local traditional crops and wild species and understand their importance for diversification and inclusion in the food basket. These district level centres can also provide access to planting material of nutritious crops and varieties, community seed banks and region- specific genetic gardens of nutri-dense crops. Training 
component is integral part of KVKs and it can implement a convergent communication campaign with uniform messaging across departments and institutions on agriculturenutrition awareness laying importance to mainstream nutrition in agriculture schemes and activities by promoting crop-based nutrition awareness approach through the various systems. Demonstration unit of model nutritional garden at various platforms will help in spreading the message.

Some efforts have been initiated in this direction through Nutri-sensitive Agricultural Resources and Innovation (NARI) and Value Addition and Technology Incubation Centres in Agriculture (VATICA) through KVKs, which will help in popularization and promotion of the biofortified crop varieties and their products. KVKs are already working on Agri-Nutri Smart Village (A2N) Model which focuses on Nutri Farming System, Agri-Nutri Education, Agri-Nutri Capacity Building and SHG Farmer Nutri Clubs. There are 704 KVKs across the country, with one in almost each district and $44 \mathrm{KVKs}$ in Bihar. These KVKs are supported by a robust capacity building and support structure. The National Agricultural Research Education and Extension System, which serves the agricultural technology and information needs of the country, has created a research network of 102 Indian Council of Agriculture Research Institutes, 11 Agricultural Technology Application Research Institutes (ATARIs) and 73 State Agricultural Universities (including 3 Central Agricultural Universities and 5 Universities with Agriculture Faculty) spread across the country which support KVKs. Dr. Rajendra Prasad Agriculture University, Bihar who with support from UNICEF have established an agri-nutrition cell in the university, piloted and scaled up school nutrition garden initiative (Ankuran) now active in 70,000 schools state wide, supporting nutrition sensitive farming through Krishi Mitras or village resource persons (VRPs), SHGs and their federations (under project Swabhimaan) and now also started working on comprehensive management of severe acute malnutrition.

\section{Ankuran project}

Bihar had the highest percentage of stunted (sub-optimal height-for-age) children among all the states, according to the October 2019 Comprehensive National Nutrition Survey (CNNS). Forty-two percent of children under the age of five in Bihar were stunted, a significantly higher proportion compared to the all-India average of $34.7 \%$. The state also had a higher proportion of underweight children--38.7\% compared to the national average of $33.4 \%$. The CNNS also found that a higher percentage of children in Bihar had vitamin A, vitamin D and zinc deficiencies than the national average. Iron, folate and vitamin B12 deficiencies were less common in the state compared to all-India levels. Close to a third of children between five and nine years and adolescents between the ages of 10 and 19 in Bihar were anaemic. Among smaller children, these rates were much higher, with $43.9 \%$ of one to four-yearolds being anaemic, against $40.6 \%$ nationwide.

Ankuran a Sanskrit word, which means to sprout, is a part of Bihar's 2016 Swabhimaan programme, which aimed to improve the nutritional status of girls, pregnant women and mothers of children less than two years. In this pilot Ankuran project, UNICEF India gave 100 schools in Purnea district a one-time grant of Rs 10,000 each to set up nutrition gardens along with training, monitoring and logistics support to the programme. Ankuran was scaled in 2017 to cover 20,000 schools across Bihar where micronutrient deficiency and malnutrition 
lead to a significant number of child mortalities. This Ankuran programme, run by Bihar's health, education and agriculture ministries, aims to nudge children to eat more nutritious food. It involves creating nutrition and hygiene awareness among students as well as setting up children-run nutrition gardens, or poshan vatikas, in schools. For the pilot, the ideal size of the garden was determined to be 225 square feet. Schools were selected for these gardens based on the availability of land. The land was divided into multiple plots where a variety of vegetable seeds were planted and grown organically.

Table.1 Share of Agriculture Sector in Gross State Value Added (2013-14 to 2018-19)

\begin{tabular}{|l|l|l|l|l|l|l|}
\hline Sector & $\begin{array}{l}\mathbf{2 0 1 3}- \\
\mathbf{1 4}\end{array}$ & $\begin{array}{l}\mathbf{2 0 1 4} \\
\mathbf{1 5}\end{array}$ & $\begin{array}{l}\mathbf{2 0 1 5 -} \\
\mathbf{1 6}\end{array}$ & $\begin{array}{l}\mathbf{2 0 1 6 -} \\
\mathbf{1 7}\end{array}$ & $\mathbf{2 0 1 7 - 1 8 ( P )}$ & $\mathbf{2 0 1 8 - 1 9 ( Q )}$ \\
\hline $\begin{array}{l}\text { Agriculture, Forestry and } \\
\text { Fishing }\end{array}$ & 22.8 & 22.0 & 21.2 & 21.6 & 21.0 & 19.3 \\
\hline Crops & 14.2 & 13.1 & 12.4 & 12.7 & 12.1 & 10.6 \\
\hline Livestock & 5.4 & 5.7 & 5.7 & 5.6 & 5.6 & 5.6 \\
\hline Forestry and Logging & 1.7 & 1.6 & 1.5 & 1.8 & 1.6 & 1.6 \\
\hline Fishing and Aquaculture & 1.6 & 1.7 & 1.7 & 1.5 & 1.6 & 1.5 \\
\hline
\end{tabular}

Data of 2017-18 is Provisional Estimates and of 2018-19 is Quick Estimates Source: Directorate of Economics and Statistics, GoB (Bihar Economic Survey 19-20)

Table.2 Cropping Pattern (2014-15 to 2018-19, in percent)

\begin{tabular}{|l|c|c|c|c|c|}
\hline Crop & $\mathbf{2 0 1 4 - 1 5}$ & $\mathbf{2 0 1 5 - 1 6}$ & $\mathbf{2 0 1 6 - 1 7}$ & $\mathbf{2 0 1 7 - 1 8}$ & $\mathbf{2 0 1 8 - 1 9}$ \\
\hline Foodgrains & 93.23 & 93.26 & 91.63 & 93.72 & 94.04 \\
\hline Cereals & 86.15 & 86.19 & 84.88 & 86.94 & 87.10 \\
\hline Pulses & 7.09 & 7.07 & 6.76 & 6.77 & 6.94 \\
\hline Oilseeds & 1.63 & 1.70 & 1.49 & 1.46 & 1.46 \\
\hline Fibre Crops & 1.57 & 1.58 & 3.59 & 1.50 & 1.24 \\
\hline Sugarcane & 3.56 & 3.46 & 3.28 & 3.33 & 3.26 \\
\hline Total Area & 100 & 100 & 100 & 100 & 100 \\
\hline
\end{tabular}

Source: Directorate of Economics and Statistics, GoB

Table.3 Causes of Under-nutrition in rural areas of Bihar and India, 2015-16

\begin{tabular}{|c|c|c|}
\hline Indicators & Bihar & India \\
\hline \multicolumn{3}{|l|}{ Causes } \\
\hline Children under age 3 years breastfed within one hour of birth (\%) & 34.2 & 41.1 \\
\hline Children under age 6 months exclusively breastfed (\%) & 54.2 & 56.0 \\
\hline $\begin{array}{l}\text { Children age 12-23 months fully immunized (BCG, measles, and } 3 \\
\text { doses each of polio and DPT) }(\%)\end{array}$ & 61.9 & 61.3 \\
\hline Pregnant women age 15-49 years who are anaemic $(\%)$ & 58.0 & 52.1 \\
\hline All women age 15-49 years who are anaemic $(\%)$ & 60.5 & 54.2 \\
\hline
\end{tabular}

Source: Bihar State Nutrition Action Plan 2019-24 Department of Social Welfare Government of Bihar 
Table.4 Nutrient available in commonly grown vegetables under IFS

\begin{tabular}{|c|c|c|c|c|c|c|c|c|c|c|c|}
\hline Nutrients & Spinach & Amaranth & Coriander & carrot & Radish & Chilli & Tomato & Brinjal & Ladyfinger & $\begin{array}{l}\text { Ridge } \\
\text { Gourd }\end{array}$ & Total \\
\hline Iron (mg) & 66.84 & 26.18 & 0.73 & 1.03 & 0.4 & 20 & 3.2 & 3.0 & 2.0 & 1.5 & 106.85 \\
\hline Zinc (mg) & 18.0 & 2.02 & 0.16 & - & - & - & 2.0 & 3.0 & - & 1.0 & 26.2 \\
\hline Calcium (mg) & 4380 & 2978 & 199 & 80 & 35 & 30 & 240 & 130 & 20 & 60 & 8152 \\
\hline $\begin{array}{l}\text { Pro vitamin } \mathrm{A} \\
(\mu \mathrm{g})\end{array}$ & 56.64 & 6.26 & 0.24 & 0.65 & - & 0.3 & 0.3 & - & - & - & 64.39 \\
\hline Vitamin $C(\mu g)$ & 1680 & 742.5 & 70 & 1.5 & 25 & 300 & 135 & 90 & - & 20 & 3052.8 \\
\hline
\end{tabular}

Table.5 Nutritional value of some common food ingredients other than vegetables. (Per $100 \mathrm{~g}$ on fresh weight basis)

\begin{tabular}{|c|c|c|c|c|c|c|c|c|c|c|}
\hline Food & $\begin{array}{c}\text { Carbohydrates } \\
\text { (gm) }\end{array}$ & $\begin{array}{l}\text { Protein } \\
\text { (gm) }\end{array}$ & $\begin{array}{l}\text { Fat } \\
\text { (gm) }\end{array}$ & $\begin{array}{l}\text { Calorie } \\
\text { (energy) }\end{array}$ & $\begin{array}{c}\text { Vit A } \\
\text { IU }\end{array}$ & $\begin{array}{c}\text { Thiamine } \\
\text { (mg) }\end{array}$ & $\begin{array}{l}\text { Riboflavin } \\
\text { (mg) }\end{array}$ & $\begin{array}{l}\text { Calcium } \\
\text { (mg) }\end{array}$ & $\begin{array}{c}\mathbf{F e} \\
(\mathbf{m g})\end{array}$ & $\begin{array}{c}\text { Vitamin C } \\
(\mathrm{mg})\end{array}$ \\
\hline Rice & 70.0 & 6.4 & 0.4 & 345.0 & 15.0 & 0.21 & 0.09 & 24.0 & 0.8 & - \\
\hline Plain Flour & 69.4 & 12.1 & 1.7 & 341.0 & 95.7 & 0.55 & 0.12 & 41.0 & 3.3 & - \\
\hline Husked Flour & 73.9 & 11.0 & 11.0 & 348.0 & - & 0.12 & 0.07 & 23.0 & 2.5 & - \\
\hline Gram & 59.8 & 20.8 & 20.8 & 385.0 & 216.0 & 0.48 & 0.18 & 56.0 & 9.1 & 1.0 \\
\hline Green Gram & 59.9 & 24.5 & 24.5 & 358.0 & 161.7 & 0.46 & 0.21 & 75.0 & 8.5 & - \\
\hline Lentil & 59.9 & 25.1 & 25.1 & 371.0 & 450.0 & 0.45 & 0.49 & 69.0 & 4.8 & - \\
\hline Egg & - & 13.3 & 13.3 & 173.0 & 1200.0 & 0.10 & 0.18 & 60.0 & 2.1 & - \\
\hline Fish & 4.4 & 16.6 & 16.6 & 97.0 & - & 0.05 & 0.07 & 650.0 & 1.0 & - \\
\hline Mutton & 1.0 & 18.5 & 18.5 & 194.0 & 31.0 & 0.18 & 0.27 & 15.0 & 2.5 & - \\
\hline Ginger & 12.3 & 2.3 & 2.3 & 67.0 & 67.0 & 0.06 & 0.03 & 20.0 & 2.6 & 6.0 \\
\hline Turmeric & 69.4 & 13.1 & 13.1 & 376.0 & 50.0 & 0.03 & - & 150.0 & 18.6 & - \\
\hline Banana & 22.5 & 0.8 & 0.8 & 98.0 & 50.8 & 0.03 & - & 10.0 & 0.5 & 8.0 \\
\hline Guava & 11.2 & 0.9 & 0.9 & 51.0 & - & 0.50 & 0.10 & 10.0 & 1.4 & 212.0 \\
\hline
\end{tabular}


Fig.1

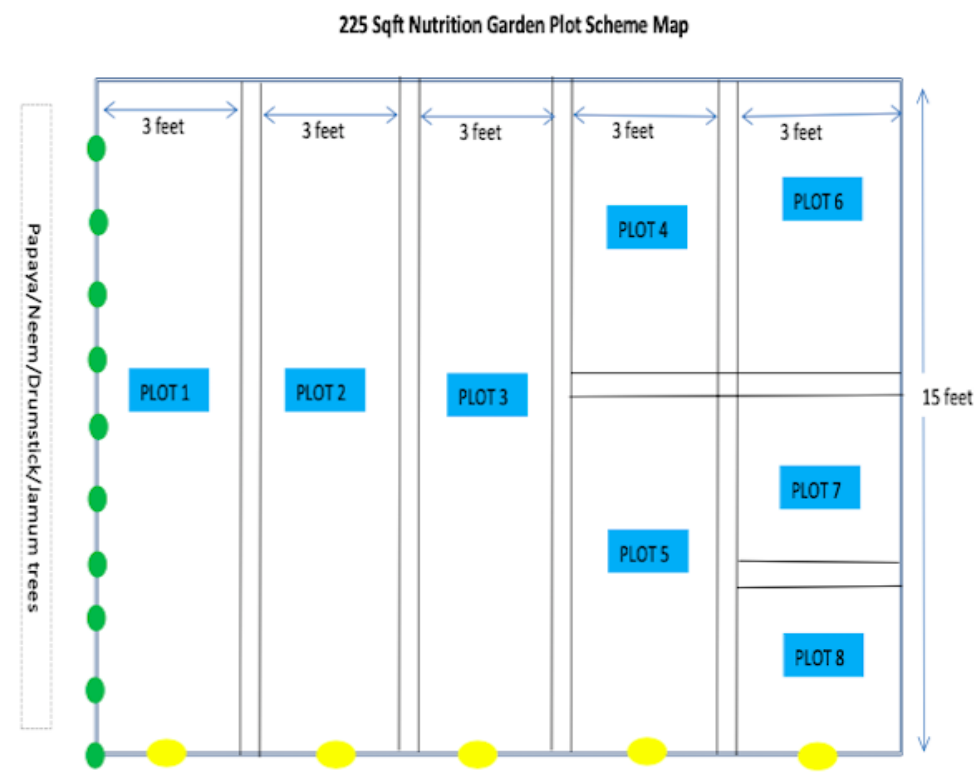

Source: Ankuran Operational Guidelines

The district Krishi Vigyan Kendra (KVK) and panchayat-level agriculture coordinators helped schools identify crops that could be planted based on the soil condition and season, as well as in preparing the garden beds and guidelines illustrated correct method of watering managing the nutritional garden. In addition, schools were provided guidelines for the nodal teacher, who had been trained to run the activities under the programme, guidelines for the poshanvatika worker or mid-day meal cook and a 'food compendium' that listed every food source available in the region and its nutritional quality. Each plot at the nutrition garden was assigned to a group of 2-3 students who took care of their respective plots.

\section{An Ideal Nutrition Garden}

Schools divide the garden into eight plots growing three vegetables on the bigger plots, and five on a smaller scale. One side of the garden should have trees. Vegetables are decided on the basis of the soil, climate and season.
The students are engaged with the fact that every meal needs to have food items of three colours yellow, white and green." The morning assembly also incorporated key awareness activities. Students were encouraged to discuss issues about nutrition and hygiene in a 30-minute session, nudge children to eat more nutritious food.

\section{Dietary diversity and Ankuran Project}

Diet diversity among adolescent girls improved in the two years that the programme had been functional in Purnea district, according to the findings of a 2018 midline survey conducted by UNICEF India in 104 villages in Kasba and Jalalgarh blocks, covering 484 households. The improvement cannot be statistically linked to the Ankuran programme as the overarching Swabhimaan programme impacted the complete district and impacted all children, not just those in government schools with vegetable gardens.

Adolescent girls between the ages of 10 and 
19 had started consuming more food groups between 2016 and 2018, according to the survey, which examined the impact of the larger Swabhimaan programme. In the programme intervention area, the mean diet diversity score--number of food groups consumed 24 hours before the survey-increased from 3.9 in 2016 to 4.87 in 2018. The scores were computed on a 10-point scale based on 10 food groups as per the methodology by the 2016 Food and Agricultural Organisation.

Adolescent girls also consumed more dark green leafy vegetables and vitamin A-rich fruits and vegetables such as carrots, spinach and locally found leafy vegetables. For instance, $62.1 \%$ of girls ate foods high in vitamin A in 2018 compared to $36.3 \%$ of girls in 2016, according to the midline survey. In the group which was not directly impacted by the Ankuran intervention, the percentage of girls eating these fruits and vegetables increased from $50.3 \%$ in 2016 to $64.3 \%$ in 2018. The Ankuran programme had been instrumental in engaging and informing students about nutrition motivating to eat more vegetables and years of consistent effort and intervention will bring about change in students' diets

In conclusions the State has the potential to capitalize on its unique natural resources in a sustainable manner to promote integrated aquaculture-agriculture-livestock systems to improve the productivity of low-lying wetlands and provide food and nutrition security throughout the year to rural population it has the opportunity to popularize integrated fish and crop farming as part of natural resource management efforts in oxbow lakes (chaurs) and floodplains (maun) and wetlands. The diversification and Integration of agriculture towards fruits and vegetables and fisheries and livestock based integrated farming system can potentially promote dietary diversity and improve nutritional outcomes with additional impetus from government with favourable nutritionsensitive agricultural policies. Agricultural policymaking across the different domains should become more nutrition-sensitive and aim to unite the twin goals of agricultural growth and nutritional improvements (Gillespie\& Kadiyala, 2012).

The study conducted by Kumar et al (2016) in 12 villages of Bihar, Jharkhand and Odisha in eastern India have shown that agricultural production diversity is a major determinant of dietary diversity which in turn has a strong effect on calorie and protein intake. The study has suggested that efforts to promote agricultural diversification will be helpful to enhance food and nutrition security in the country. In the words of M. S. Swaminathan, ".....the design of the farming system can include specific crop varieties that can address the identified deficiencies. Sweet potato might provide vitamin 'A', drumstick tree (Moringa olifera) and Amaranthus sp. could address the lack of iron." (Rao and Swaminathan, 2017). Integrated farming System approach can promotes on-farm production diversity to enhance consumption diversity for nutrition.

Agricultural intervention and farming systems research in India has been largely focussed on enhancing production, productivity and profitability of crop, animal and fisheries resources without much emphasis on better nutritional outcomes which is now a mandate for farm and non-farm families to be in nutritional security by their resource endowments and surrounding environment, thereby achieving nutritional security by different food based cropping system through improved agricultural production system, dietary diversification, income enhancement, greater nutritional awareness and changed behaviour patterns. 


\section{References}

Adhiguru, P, Ramasamy C, 2003. Agriculture Based Interventions for Sustainable Nutritional Security. Policy Paper 17, National Centre for Agricultural Economics and Policy Research and Tamil Nadu Agricultural University, Coimbatore.

Ahmad, N, Singh, KM, Sinha, DK and Mishra, RR. 2019. Food Security and Sustainability of Agricultural Production: An Economic Appraisal in Indian Context. International Journal of Chemical Studies, 7(4): 3229-3232.

Bihar State Nutrition Action Plan 2019-24 Department of Social Welfare Government of Bihar "Accelerating and harmonizing actions for Nourishing Bihar's Children" UNICEF, Bihar Field Office, Discussion paper-DRAFT 06DEC, 2015

Bala Ravi, S (2004) 'Neglected millets that save the poor from starvation,' LEISA, India, vol 6, no 1, pp.34-36.

Bala Ravi, S, Swain, S, Sengotuvel, D and Parida, NR (2010) 'Promoting nutritious millets for enhancing income and improved nutrition: A case study from Tamil Nadu and Orissa', in Bhag Mal, S. Padulosi, and S. Bala Ravi (eds) pp.19-46, Minor millets in South AsiaLearning from the IFAD-NUS Project in India and Nepal, Biodiversity International, Maccarese, Rome, Italy and the M.S. Swaminathan Research Foundation, Chennai, India, p.185.

Csavas, I 1992. Regional review on livestockfish production systems in Asia. In: Mukherjee, T.K., Moi, P.S., Panandam, J.M., and Yang, Y.S. (Eds.), Proceedings of the FAO/IPT Workshop on integrated livestock-fish production systems, 16-20 December 1991, Institute of Advance Studies, University of Malaya, Kuala Lumpur, Malaysia
Choudhury, M (2009) "“konidhan” - A small millet against starvation', www.merinews.com/article/konidhan-asmall-millet-against starvation/15772737.html, accessed August 2012.

Gillespie, S., \& Kadiyala, S. (2012). Exploring the agriculture-nutrition disconnect in India. Reshaping agriculture for nutrition and health. Washington DC, International Food Policy Research Institute, 173-182.

GoB. 2018. Economic Survey 2017-18, Department of Finance, Govt. Of Bihar. Accessed online (30-07-2018): http://finance.bih.nic.in/Reports/Econo mic-Survey- 2018-EN.pdf

Indian Council of Medical Research (ICMR), 2012. New Delhi, Daily Requirement of Food. Mimeo.

FAO (2010) Second report on the state of the world's plant genetic resources for food and agriculture, Commission on Genetic Resources and Agriculture, FAO, Rome, Italy.

Jayanthi, C, Rangasamy, A and Chinnusamy, C 2000. Water budgeting for components in lowland integrated farming systems. Agricultural Journal, 87:411- 414

Khondker, Murshed-e-Jahan and Pemsl, DE 2011. The impact of integrated aquaculture-agriculture on small-scale farm sustainability and farmers' livelihoods: experience from Bangladesh. Agric. Syst. 104: 392-402.

Khan, N, Dubey, M and Tiwari,US, 2015. Integrated Farming Systems: An Approach for Livelihood Security of small and marginal farmers. International Journal of Science and Nature, 6 (3): 515-520.

Kumar, A, Saroj, S, Singh, RKP and Shiv Jee .2016. Agricultural Diversity, Dietary Diversity and Nutritional Intake: An Evidence on Inter-linkages from Village 
Level Studies in Eastern India. Agricultural Economics Research Review.29 (Conf.Num.):15-29.DOI: https://doi.org/10.5958/09740279.2016 .00030 .6

Ministry of Health and Family Welfare (MoHFW), Government of India, UNICEF and Population Council. 2019. Comprehensive National Nutrition Survey (CNNS) National Report. New Delhi.

MSSRF (2017). Nutrition Sensitive Agriculture: A Pathway for Addressing Malnutrition in Bihar. Unpublished Report. Accessed online (24-01-2017): Available at http://mssrf-fsfsn.com/pdf/BIHAR/Profile_of_Bihar.p df

Nagarajan, S, Bhavani, RV, \& Swaminathan, MS. (2014). Operationalizing the concept of farming system for nutrition through the promotion of nutritionsensitive agriculture. Current Science 107(6): 959-964

Nagarajan, L and Smale, M.2007. Village seed systems and the biological diversity of millet crops in marginal environments of India. Euphytica, 155: 167-182.

National Institute of Nutrition, Hyderabad. 1980. Nutritive value of Indian Food, Mimeo.
Rao, N, Swaminathan, MS. 2017. A FarmerLed Approach to Achieving a Malnutrition-Free India. Agric Res 6: 17. https://doi.org/10.1007/s40003-0160240-8

Pingali, P. 2012. Green Revolution: impacts, limits, and the path ahead, Proceedings of the National Academy of Sciences USA, 109:12302-12308

Pingali, P. (2015) 'Agricultural policy and nutrition outcomes - getting beyond the preoccupation with staple grains', Food Security, 7: 583-591.

Singh, KM, Ahmad, N, Sinha, DK and Mishra, RR. 2019. Factors Affecting Nutritional Status of India: An Economic Analysis with Special Reference to Agricultural Performance. Multilogic in Science, 9 (31):117-121.

Singh, KM and Singh, P. 2020. NutritionalSensitive and Sustainable Agricultural Development - An Overview. Functional Foods, Health, \& Nutrition eJournal, 2 (4). Available at http://dx.doi.org/10.2139/ssrn.3518382

Singh, KM and Singh, P. 2020. Challenges of Ensuring Food and Nutritional Security in Bihar. Development Economics: Macroeconomic Issues in Developing Economies eJournal,9 (23). Available at http://dx.doi.org/10.2139/ssrn.3517106

\section{How to cite this article:}

Singh, K. M., Pushpa Singh and Binita Rani. 2021. Food and Nutritional Security Initiatives in Bihar (India): An Overview. Int.J.Curr.Microbiol.App.Sci. 10(01): 3174-3786.

doi: https://doi.org/10.20546/ijcmas.2021.1001.370 